\title{
Stepwise engineering of a Pichia pastoris D-amino acid oxidase whole cell catalyst
}

\author{
Sandra Abad'1, Jozef Nahalka1,2,3, Gabriele Bergler'1, S Alison Arnold4, Robert Speight4, lan Fotheringham4, \\ Bernd Nidetzky1,2 and Anton Glieder*1
}

\begin{abstract}
Background: Trigonopsis variabilis D-amino acid oxidase (TVDAO) is a well characterized enzyme used for cephalosporin C conversion on industrial scale. However, the demands on the enzyme with respect to activity, operational stability and costs also vary with the field of application. Processes that use the soluble enzyme suffer from fast inactivation of TVDAO while immobilized oxidase preparations raise issues related to expensive carriers and catalyst efficiency. Therefore, oxidase preparations that are more robust and active than those currently available would enable a much broader range of economically viable applications of this enzyme in fine chemical syntheses. A multi-step engineering approach was chosen here to develop a robust and highly active Pichia pastoris TvDAO whole-cell biocatalyst.

Results: As compared to the native T. variabilis host, a more than seven-fold enhancement of the intracellular level of oxidase activity was achieved in P. pastoris through expression optimization by codon redesign as well as efficient subcellular targeting of the enzyme to peroxisomes. Multi copy integration further doubled expression and the specific activity of the whole cell catalyst. From a multicopy production strain, about $1.3 \times 10^{3} \mathrm{U} / \mathrm{g}$ wet cell weight (wcw) were derived by standard induction conditions feeding pure methanol. A fed-batch cultivation protocol using a mixture of methanol and glycerol in the induction phase attenuated the apparent toxicity of the recombinant oxidase to yield final biomass concentrations in the bioreactor of $\geq 200 \mathrm{~g} / \mathrm{L}$ compared to only $117 \mathrm{~g} / \mathrm{L}$ using the standard methanol feed. Permeabilization of P. pastoris using 10\% isopropanol yielded a whole-cell enzyme preparation that showed $49 \%$ of the total available intracellular oxidase activity and was notably stabilized (by three times compared to a widely used TVDAO expressing Escherichia coli strain) under conditions of D-methionine conversion using vigorous aeration.
\end{abstract}

Conclusions: Stepwise optimization using a multi-level engineering approach has delivered a new P. pastoris whole cell TVDAO biocatalyst showing substantially enhanced specific activity and stability under operational conditions as compared to previously reported preparations of the enzyme. The production of the oxidase through fed-batch bioreactor culture and subsequent cell permeabilization is high-yielding and efficient. Therefore this P. pastoris catalyst has been evaluated for industrial purposes.

\section{Background}

D-Amino acid oxidases (DAO, E.C. 1.4.3.3) are well characterized flavoenzymes that have been considered for various applications during the last 20 years. Among these applications, the industrial use of DAO to catalyze the first step of chemo-enzymatic conversion of cephalosporin $\mathrm{C}$ to 7 -aminocephalosporanic acid [1] is an out-

\footnotetext{
*Correspondence: anton.glieder@acib.at

${ }^{1}$ Austrian Centre of Industrial Biotechnology, c/o Applied Biocatalysis Research Centre, c/o Institute of Molecular Biotechnology, Graz University of Technology, Petersgasse 14, 8010 Graz, Austria

Full list of author information is available at the end of the article
}

standing example. It represents the only known case of a large-scale $(>1000$ tons/year) biocatalytic process employing an oxidase as biocatalyst (Figure 1A). Other promising applications of DAO include the production of $\alpha$-keto acids [2], analytical determination of D-amino acids in biological samples and foodstuffs [3], the development of DAO biosensors [4] for analytics, and the elimination of traces of D-amino acids from non-natural L-amino acid preparations [5]. More recently, the use of DAO for the chemo-enzymatic synthesis of physiologically active compounds (e.g. L-methionine, phenyl pyruvate, L-6-hydroxynorleucine, L-2-naphtylalanine) has 


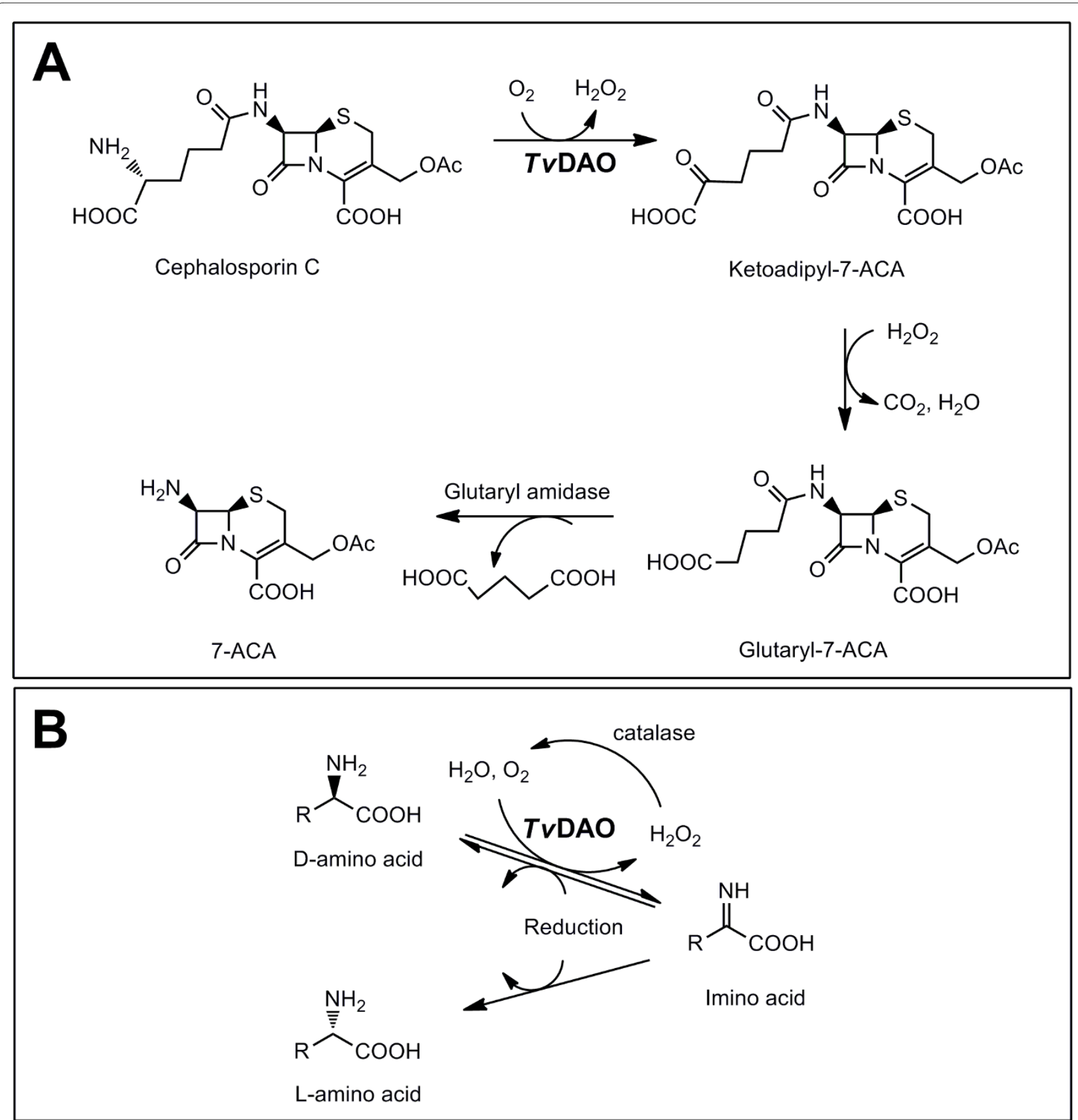

Figure 1 Industrial applications of TVDAO. A: Chemo-enzymatic conversion of cephalosporin C to 7-aminocephalosporanic acid. Spontaneous decarboxylation of ketoadipyl-7-ACA (amino cephalosporanic acid) is promoted by the $\mathrm{H}_{2} \mathrm{O}_{2}$ formed in the oxidase reaction of TVDAO. B: Chemoenzymatic production of pure enantiomers of amino acids by amino acid oxidases in combination with imine reduction benefits from the additional presence of a catalase that destroys $\mathrm{H}_{2} \mathrm{O}_{2}$.

reinforced the applied potential of this enzyme [6]. Figure $1 \mathrm{~B}$ is a schematic representation of a deracemisation process employing DAO in its first step and scaled up for industrial application [5].

DAO from the yeast Trigonopsis variabilis (TvDAO) [7] was the preferred choice of catalyst for cephalosporin $C$ conversion, primarily because it was more efficient on the industrial substrate than other known DAOs, such as enzymes from Rhodotorula gracilis and pig kidney for example [8]. T. variabilis also showed higher productivity (volumetric and specific) for biosynthesis of DAO than relevant other native producers of the oxidase [8].

The operational stability of TvDAO in biocatalytic conversions has always been a critical issue in process devel- 
opment and has therefore attracted considerable attention. Enzymatic conversion of cephalosporin $\mathrm{C}$ depends on $\mathrm{O}_{2}$ as co-substrate and furthermore relies on the $\mathrm{H}_{2} \mathrm{O}_{2}$ produced in the enzymatic reaction (Figure $1 \mathrm{~A}$ ). While isolated TvDAO is sensitive to the conditions applied in the process (bubble aeration, high concentration of oxidants), carrier-bound and entrapped immobilisates of the enzyme showed enhanced persistence $[9,10]$. However, demands on the enzyme with respect to activity and stability but also with respect to the costs incurred vary with the process considered. For simple oxidations in fine chemical production, the $\mathrm{H}_{2} \mathrm{O}_{2}$ usually has to be removed to avoid enzyme inactivation. To our knowledge, a preparation of $T v \mathrm{DAO}$ fulfilling the requirements of a broad-scope biocatalyst for fine chemical synthesis was not previously available.

While TvDAO production in the native host presents industrial standard, enhancement of specific as well as volumetric productivity as compared to $T$. variabilis is also desirable (see later). Heterologous expression in $E$. coli has provided oxidase preparations having fine-tuned stability [10,11], activity [12] and even solubility [13]. A number of yeasts including Kluveromyces lactis [14], Saccharomyces cerevisiae [14], a catalase-deficient strain of Schizosaccharomyces pombe [15] and the methylotrophic yeast $P$. pastoris $[16,17]$ have also been employed for recombinant production of $T \nu \mathrm{DAO}$.

Contrary to cephalosporin $\mathrm{C}$ conversion where $\mathrm{H}_{2} \mathrm{O}_{2}$ formed in the reaction of TvDAO is crucial to promote oxidative decarboxylation of the $\alpha$-keto acid product (Figure $1 \mathrm{~A})$, processes for production of chiral amino acids (see Figure 1B) benefit from reduced by-product formation at low peroxide levels (see [18]). A whole-cell biocatalyst producing both TvDAO and catalase in large amounts would therefore be beneficial and the methylotrophic yeast $P$. pastoris seemed to be an ideal point of departure for its development. Heterologous gene expression in $P$. pastoris is often performed under control of the very strong alcohol oxidase 1 promoter $\left(\mathrm{P}_{\text {AOX1 }}\right)$ [19] which becomes fully induced when methanol is utilized as the sole carbon source. In addition to promoting recombinant protein production, these conditions also lead to an extensive proliferation of peroxisomes, which can cover up to $80 \%$ of the cytoplasmic space [20]. Efficient targeting of recombinant TvDAO into peroxisomes of $P$. pastoris would allow to make efficient use of this intracellular space for the over-expressed protein and at the same time, co-localize the enzyme producing $\mathrm{H}_{2} \mathrm{O}_{2}$ with the one destroying it (i.e. the endogenous catalase [21]). Another plausible advantage of having TvDAO and catalase in the same cellular compartment is that conversion of $\mathrm{H}_{2} \mathrm{O}_{2}$ by catalase recycles $\mathrm{O}_{2}$ for the oxidase reaction. Previously described $P$. pastoris strains over- expressing the TvDAO gene displayed only modest productivity $[16,17,22]$. Driven by a clear industrial demand (Figure 1B) and using a stepwise engineering approach, this paper reports on the successful design and generation of an innovative and notably improved $P$. pastorisbased DAO biocatalyst.

\section{Results and Discussion}

\section{Expression engineering}

Expression engineering to optimise oxidase production involved the re-design of both the gene and the amino acid sequence of TvDAO. The coding gene was optimized for expression in $P$. pastoris according to the codon usage of genes that provide high levels of recombinant protein under methanol induction conditions for $\mathrm{P}_{A O X 1}$ (see Material and methods). Like other DAOs, TvDAO was assumed to be localized in the peroxisomes of the native host [14]. A targeting sequence recognized by either one of the common transport proteins Pex $5 p$ and Pex7p is a general requirement for peroxisomal protein import. A bioinformatic analysis of the TvDAO primary structure using TargetP 1.1 [23] and PSORTII [24] revealed the absence of a Pex7p-selective motif PTS2. The occurrence of PTS1, the sequence recognized by Pex5p, was uncertain using publicly available predictor software $[25,26]$ but indicated the C-terminal peptide -Pro-Asn-Leu (PNL) as a putative PTS1. With the aim of enhancing peroxisomal transport of the enzyme under conditions of heterologous expression, we exchanged the native PNL motif by the well known peroxisomal targeting sequence -Ser-Lys-Leu (SKL) which has previously been successfully exploited to achieve peroxisomal localisation of recombinant green-fluorescent protein in P. pastoris [27].

Four different gene combinations were obtained by combining native and codon-optimized genes with the Cterminal sequence motifs SKL and PNL. This permutation was necessary because of the currently limited ability to predict the actual success of codon optimization. These DAO variants were combined with the necessary 5 'and 3' DNA sequences for expression cassettes delivering chromosomal integration in $P$. pastoris and expression under control of $\mathrm{P}_{A O X 1}$. Pichia transformants were cultivated in 96-well format [28] and screened for putative single copy strains using an enzyme-coupled assay for fast detection of DAO activity. This was done under the assumption that expression increases with increasing copy numbers of integrated expression cassettes. Only single copy strains allow the comparison of the effect of individual gene constructs. Quantitative real time-PCR was then used to analyze the selected strains, and the results confirmed that comparable number of expression cassettes (1-2 copies) had been integrated in each strain.

These "low-copy-number" strains were compared with respect to biomass formation and enzyme production in 
Table 1: Enzyme and strain engineering for efficient expression of TvDAO in Pichia pastoris.

\begin{tabular}{|c|c|c|c|c|c|}
\hline \multirow[t]{2}{*}{ Strain } & \multicolumn{2}{|c|}{ Sequence } & \multirow[t]{2}{*}{$\mathrm{CN}$} & \multirow{2}{*}{$\begin{array}{c}\text { Intracellular } \\
\text { activity }\end{array}$} & \multirow{2}{*}{$\begin{array}{c}\text { Biomass } \\
\text { [g wcw/batch] }\end{array}$} \\
\hline & Codon usage & PTS1 & & & \\
\hline Tv5al & native & PNL & 1 & 137 & 220 \\
\hline Tv1all & native & SKL & 1 & 90 & 274 \\
\hline Tv51 & optimized & PNL & $1-2$ & 348 & 259 \\
\hline Tv1" & optimized & SKL & 1 & 767 & 144 \\
\hline Tv1a_mcll & optimized & SKL & 5 & 550 & 240 \\
\hline Tv1_mcll & optimized & SKL & $16-17$ & 1283 & 117 \\
\hline
\end{tabular}

'PNL sequence: 5'-CCA-AAC-CTT-3'; "SKL sequence: 5'-TCC-AAG-CTG-3'

Enzyme activities are reported for $P$. pastoris cells obtained in 1.5-L bioreactor cultivation employing standard induction with $3 \mathrm{~mL} / \mathrm{min}$ methanol. Codon usage: native as in the original TVDAO gene, or optimized for expression using the AOX1 promoter. PTS1 - peroxisomal targeting using the native C-terminal tripeptide PNL or the engineered motif SKL. CN: Number of copies of the expression cassette integrated into the P. pastoris genome. wcw: wet cell weight. Activity measurements were performed three times revealing a standard deviation of $<$ $10 \%$.

1.5-liter bioreactor cultivations (Table 1). Among the four strains, the strain Tv1 harbouring the codon-optimized gene for production of TvDAO-SKL showed the highest $\mathrm{DAO}$ activity. The exchange of the native putative peroxisomal targeting sequence -PNL to -SKL had no positive effect on enzyme production when the native gene was used (strains Tv5a and Tv1a). However, the same substitution brought a substantial increase in oxidase activity when comparing the codon-optimized genes (strains Tv5 and Tv1). The engineering strategies directed towards codon optimization, which is expected to facilitate translation and optimized subcellular targeting at the same time resulted in a synergistic effect on whole cell TvDAO activity. Strain Tv1 showed an about 5-fold improvement in specific oxidase activity as compared to the reference strain Tv5a. To our knowledge, this is the first report describing a combination of PTS1 exchange with codon optimization of a gene to improve intracellular expression.

All low copy strains except Tv1 which integrated a single copy of the expression cassette containing the codon optimized DAO gene with -SKL C-terminal end, allowed biomass concentrations well above $200 \mathrm{~g} / \mathrm{L}$ using standard $P$. pastoris cultivation procedures including methanol feed in the production phase. A relatively lower biomass yield of $144 \mathrm{~g} \mathrm{wcw} /$ batch for Tv1 employing the same cultivation conditions might be explained by the stress, which is generated when large amount of recombinant DAO accumulate in the cell. The strain Tv1 grew normally in glycerol containing media where $T v \mathrm{DAO}$ expression was repressed, but not during the induction phase using methanol. Similar observations were made with other yeast host organisms, where reduced growth during induction due to an apparent cell toxicity of recombinant DAO was reported $[14,16]$.

\section{Development of a high-yielding production strain}

The codon-optimized gene for TvDAO-SKL was used for further strain development. A new expression construct was made employing the expression vector $\mathrm{pPpB} 1$, which facilitates the generation and detection of $P$. pastoris multi-copy transformants. Using activity-based screening of $P$. pastoris transformants, the best active strain denoted Tv1_mc was selected. Characterization by real time-PCR revealed integration of about $16-17$ copies of the expression cassette. Table 1 shows that the Tv1_mc strain gave a twofold enhancement of specific oxidase activity as compared to the single copy clone Tv1. This result implies that the number of gene copies did not translate linearly into an increasing titre of active TvDAO. Notwithstanding, Tv1_mc is the most efficient host for TvDAO production that has been reported so far. A comparison with earlier reports shows that this strain reached an expression level up to 1.5 and 1 order of magnitude above the expressions levels reported for $E$. coli and $P$. pastoris, respectively $[13,17]$. Other yeasts such as $S$. cerevisiae and $K$. lactis showed significant lower TvDAO production [14]. Unfortunately, the biomass yield for the multi copy transformant Tv1_mc was even lower than in case of the strain Tv1. As with Tv1, growth was impaired only during induction with methanol. For comparison reasons we constructed another multi-copy strain of $P$. pastoris, termed Tv1a_mc (native gene with -SKL). This strain produced a lower amount of TvDAO activity (550 U/g wcw) than the strains Tv1 and Tv1_mc containing codon optimized genes and it grew normally in the methanol feeding phase. This finding further supports the 
notion that the recombinant oxidase, at least when it exceeds a certain level in the cell, seems to be inhibitory to $P$. pastoris growth. We therefore considered optimization of the cultivation and induction conditions for recombinant DAO protein production by the best strain Tv1_mc.

Using the methanol feed of $3 \mathrm{~mL} / \mathrm{h}$ as a benchmark, alternative strategies for fed-batch cultivation of Tv1_mc were evaluated. It was known [29-32] that a mixed substrate feed in the induction phase can support $P$. pastoris growth and productivity for the target protein at the same time. Figure 2 depicts the results obtained using feeds of glucose-methanol and glycerol-methanol (each at $3 \mathrm{~mL} /$ h) and a reduced pure methanol feed at $1.5 \mathrm{~mL} / \mathrm{h}$. The switch from pure methanol feed to mixed substrate feed caused an about $40 \%$ increase in biomass yield ( $200 \mathrm{~g}$ wcw/batch) without compromising the specific activity of the yeast cells. Glycerol-methanol was superior to glucose-methanol at the evaluated feed rate. On the other hand a reduced flow rate $(1.5 \mathrm{~mL} / \mathrm{h})$ of the methanol feed resulted in a 1.4-fold enhancement of specific activity as compared to the reference, while the biomass yield remained rather low ( $\sim 140 \mathrm{~g} /$ batch $)$.

However the volumetric productivity under these conditions was the highest. The Tv1_mc cells subjected to induction by a reduced methanol feed gave a volumetric oxidase yield of $218 \mathrm{kU} / \mathrm{L}$ and a productivity of $2.0 \mathrm{kU} /(\mathrm{h}$ L). In comparison the Tv1_mc strain fed with glycerolmethanol resulted in lower yields of $167 \mathrm{kU} / \mathrm{L}(1.5 \mathrm{kU} /$ $\mathrm{hL})$, and $152 \mathrm{kU} / \mathrm{L}(1.4 \mathrm{kU} / \mathrm{hL})$ for glucose-methanol induction. These values clearly exceeded those of other

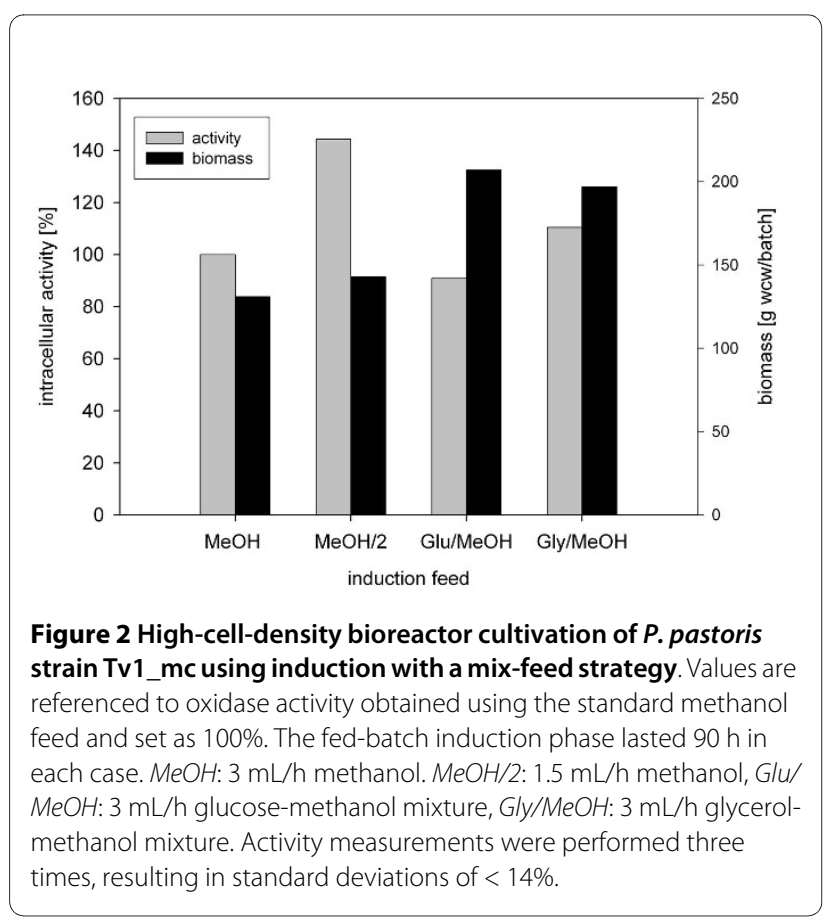

known TvDAO expression strains as summarized in Table 2.

\section{Whole cell biocatalyst optimization}

Due to already described instability issues of the enzyme a cellular "encapsulation" of the oxidase seemed a promising option. Therefore intact cells obtained in a standard bioreactor cultivation of Tv1 (methanol feed of $3 \mathrm{~mL} / \mathrm{h}$ ) were subjected to stability examination. The determination was performed according to a previously reported assay that provides a first-order inactivation constant $\left(k_{\mathrm{in}}\right)$ as measure of the operational (in)stability of the oxidase activity [10]. The value of $k_{\text {in }}$ is inversely proportional to stability, according to the relationship $\tau$ (half-life time) $=$ $\ln 2 / k_{\mathrm{in}}$. Preliminary results showed an extraordinary halflife time of more than $10 \mathrm{~h}$ for the whole cell catalyst Tv1_mc. However, based on the same oxygen consumption measurements the specific oxidase activity of intact Tv1_mc cells (5 U/g wcw) was less than $1 \%$ of the latent intracellular activity, presumably because of severe mass transfer limitations occurring in the intact cell system.

On the other hand the analysis of a lysate preparation after centrifugation was examined as the soluble fraction and the pellet fraction (probably containing partially lysed cells and peroxisomes) and showed the opposite results. The soluble fraction confirmed the high oxidase activity ( 1200 U/g wcw) measured before but a high $k_{\text {in }}$ value of $0.0208 \mathrm{~min}^{-1}(\tau=0.5 \mathrm{~h})$. Because $k_{\text {in }}$ for the partially lysed pellet fraction was only one-tenth of the value measured for the soluble fraction $\left(k_{\text {in }}\right.$ pellet fraction $=0.0026$ $\min ^{-1} ; \tau=4.4 \mathrm{~h}$ ) we still felt strongly encouraged to pursue the development of a whole-cell catalyst. $P$. pastoris TvDAO-containing Tv1_mc cells served as the starting material. While cell permeabilization was a clear option to attenuate diffusional effects, it was a challenge to prevent a trade-off between enhancement of substrate availability and loss of enzyme stability in the permeabilized whole-cell catalyst. Among various protocols proposed for yeast cell permeabilization [33], the treatment with 2propanol appeared to be most suitable for our purpose because of its simplicity, efficiency and low costs.

Batches of Tv1_mc and Tv1a_mc cells (10 g each) containing about 1300 and $500 \mathrm{U} / \mathrm{g}$ wcw intracellular activity, respectively, were lyophilized prior to treatment with isopropanol considering that handling of dried biomass is easier and more reproducible than that of wet biomass. Key variables of the permeabilization (concentrations of isopropanol and biomass, incubation time) were examined systematically. Oxidase activity measured in the treated cells was related to the total intracellular activity (Table 3). Freeze-dried cells suspended in buffer were poorly active. However, their incubation in aqueous suspension caused the gradual "appearance" of enzyme 
Table 2: Comparison of relevant host strains used for production of TvDAO.

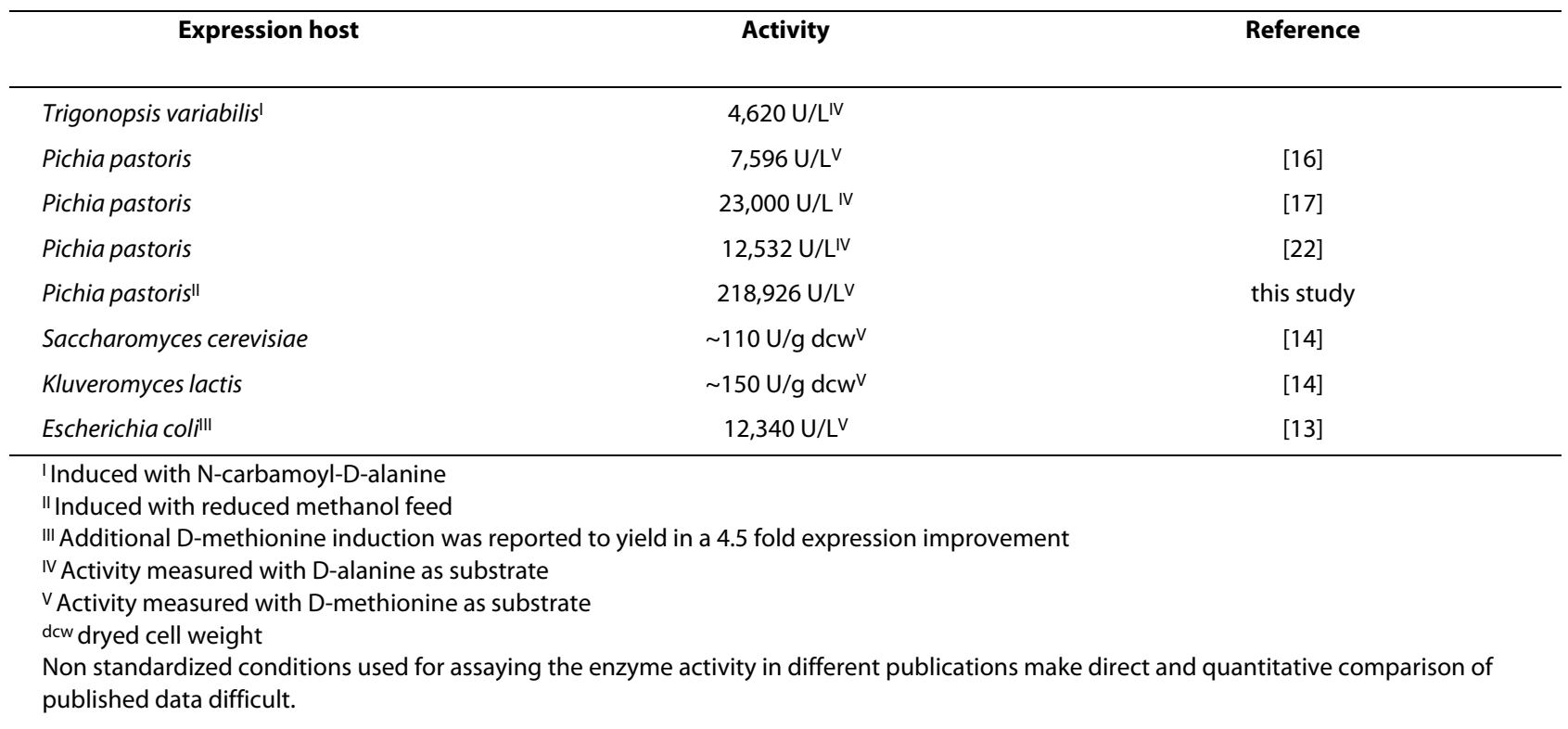

activity, reaching $\sim 20 \%$ of the maximum available activity after $20 \mathrm{~min}$. Use of isopropanol further enhanced the apparent activity, yielding an effectiveness factor $\eta(=$ apparent activity/total intracellular activity) of 0.48 (= $627 / 1300$ ) under optimized conditions where 10\% (by volume) of co-solvent was applied. A suitable incubation time was between 5.3 and $10.7 \mathrm{~h}$. Concentrations of isopropanol greater than $10 \%$ caused a decrease in $\eta$, and incubation times longer than $5 \mathrm{~h}$ did not result in further improvement. Selected whole-cell preparations showing high $\eta$ (>0.40; Table 3 ) were analyzed for the stability of the oxidase activity under operational conditions. Values of $k_{\text {in }}$ (hence, the stabilities) were not affected by the permeabilization as compared to the corresponding $k_{\text {in }}\left(k_{\text {in }}{ }^{-}\right.$ perm. cells $=0.0023 \mathrm{~min}^{-1}$ ) reaching at least the stability of the Tv1_mc pellet fraction. Different biomass concentrations in the range $4-200 \mathrm{~g} / \mathrm{L}$ were examined for permeabilization where the highest biomass level reflects the end concentration for standard fed-batch enzyme production in the bioreactor. The value of $\eta$ obtained through permeabilization in the presence of $10 \%$ isopropanol was independent of the biomass concentration although the time required to achieve a maximum level of apparent activity increased with increasing biomass concentration (Figure 3). The stability of the whole-cell catalysts was not affected by the variation of biomass concentration during permeabilization. These results led to the conclusion that the permeabilization of Tv1_mc delivered a novel and promising whole-cell catalyst that was equally active $(\sim 500 \mathrm{U} / \mathrm{g}$ wcw) but three times more stable than the reported E. coli oxidase preparations [13]. The stability of TvDAO in permeabilized lyophilized $P$. pastoris cells rela- tive to the cell free $P$. pastoris preparation was enhanced by one order of magnitude.

\section{Conclusions}

A multi-level engineering approach was successfully applied to develop an innovative whole-cell enzyme preparation of TvDAO that is suitable for applications in industrial deracemization processes (Figure 1B). The outstanding capabilities of $P$. pastoris in recombinant protein production were harnessed to provide high specific activ-

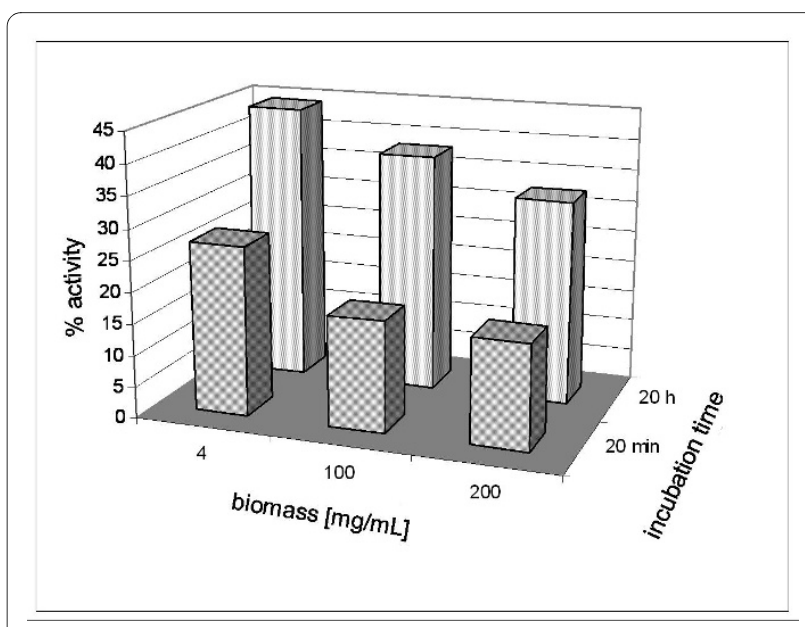

Figure 3 Effect of biomass concentration on permeabilization of recombinant Pichia pastoris cells expressing TVDAO. Cells of TV1_mc cultivated in a bioreactor were treated with isopropanol for 20 min and $20 \mathrm{~h}$. The activity of permeabilized cells is given as a percentage of the total intracellular activity $(1283 \mathrm{U} \mathrm{g} / \mathrm{Wcw})$ measured after cell lysis. Activity measurements were performed three times resulting in standard deviations of $<5 \%$. 
Table 3: Systematic optimization of process variables for the permeabilization of $P$. pastoris cells expressing TvDAO.

\begin{tabular}{|c|c|c|c|c|c|}
\hline \multirow{2}{*}{$\begin{array}{l}\text { Isopropanol } \\
\text { concentration }\end{array}$} & \multirow[b]{2}{*}{ Incubation time } & \multicolumn{4}{|c|}{ Accessible activity after permeabilization } \\
\hline & & \multicolumn{2}{|c|}{ Tv1a_mc } & \multicolumn{2}{|c|}{ Tv1_mc } \\
\hline$[\%$, by vol.] & [h] & {$[U / g$ wcw $]$} & $\eta$ & {$[\mathrm{U} / \mathrm{g} \mathbf{w c w}]$} & $n$ \\
\hline- & - & 6 & $\sim 0.01$ & 5 & $<0.01$ \\
\hline 0 & 0.3 & 100 & 0.20 & 321 & 0.23 \\
\hline 4 & 0.3 & 118 & 0.23 & & \\
\hline 8 & 0.3 & 141 & 0.28 & & \\
\hline 10 & 0.0 & 100 & 0.20 & & \\
\hline 10 & 0.3 & 184 & 0.36 & 430 & 0.33 \\
\hline 10 & 0.7 & 193 & 0.38 & & \\
\hline 10 & 1.5 & 206 & 0.41 & & \\
\hline 10 & 2.5 & & & 579 & 0.45 \\
\hline 10 & 3.0 & 226 & 0.45 & & \\
\hline 10 & 5.3 & & & 627 & 0.49 \\
\hline 10 & 10.7 & & & 621 & 0.48 \\
\hline 12 & 0.3 & 176 & 0.35 & 424 & 0.33 \\
\hline 15 & 0.3 & 170 & 0.34 & & \\
\hline 20 & 0.3 & 64 & 0.13 & & \\
\hline 40 & 0.3 & 14 & 0.03 & & \\
\hline
\end{tabular}

The accessible activity is the activity of the whole-cell system after permeabilization, as measured in U/g wcw and expressed as $\eta$, the effectiveness factor (= apparent activity/total intracellular activity), whereas the total intracellular activity was determined after cell disruption with a French Press. Strains Tv1a_mc and Tv1_mc contained 550 and 1283 U/g wcw of total intracellular activity, respectively. Lyophilized Pichia cells were used for permeabilization with a concentration being constant at $4 \mathrm{mg} / \mathrm{mL}$. Results in the first row referred to experiments carried out with intact cells obtained from one standard bioreactor cultivation. Permeabilization was performed three times per defined condition, with a standard deviation of the effectiveness factors of $<5 \%$.

ity $(1.3 \mathrm{kU} / \mathrm{g}$ wcw) and, due to high cell density cultivation of $P$. pastoris, also very high volumetric oxidase activities $(150 \mathrm{kU} / \mathrm{L})$ under standard induction conditions, which could be improved by a reduced methanol feed $(218 \mathrm{kU} / \mathrm{L})$. These values are well above the highest levels reported in literature (see Table 2). Mild permeabilization of the Pichia biomass allowed about half of the latent intracellular activity to be utilized, while at the same time retaining the good operational stability of the enzyme entrapped in the cell matrix of P. pastoris peroxisomes. Peroxisomal targeting might be a generally useful strategy of producing recombinant oxidases in P. pastoris, especially under circumstances where a whole-cell catalyst preparation is considered and immediate removal of the $\mathrm{H}_{2} \mathrm{O}_{2}$ generated in the enzymatic reaction is desired. In addition, when protein expression is induced by methanol induction, increased peroxisome formation provides increased capacity for the expressed and targeted oxidase. Due to these advantages a $P$. pastoris-based whole-cell TvDAO preparation and deracemisation processes (Figure 1B) are being scaled up and the new TvDAO whole cell catalyst can be rapidly integrated into the existing process.

\section{Methods}

\section{Chemicals and media}

Oligonucleotides were purchased from IDT Integrated DNA Technologies BVBA (Leuven, Belgium) or Invitrogen Corp. (Carlsbad, CA, USA). Sterile water was from Fresenius Kabi Austria (Graz, Austria). All DNA-modifying enzymes were obtained from Fermentas GmbH (Burlington, Ontario, Canada). Unless otherwise stated, all chemicals were from Carl Roth GmbH (Karlsruhe, Germany), Becton, Dickinson and Company (Franklin Lakes, NJ, USA) or Sigma-Aldrich (St Louis, MO, USA).

Complex media contained $10 \mathrm{~g} / \mathrm{L}$ yeast extract, $20 \mathrm{~g} / \mathrm{L}$ peptone and $20 \mathrm{~g} / \mathrm{L}$ glucose (YPD). Media for plates were solidified by addition of agar to $1.5 \% \mathrm{w} / \mathrm{v}$. The minimal media used in this work contained $200 \mathrm{mM}$ potassium phosphate buffer ( $\mathrm{pH} 6.0), 13.4 \mathrm{~g} / \mathrm{L}$ yeast nitrogen base and $0.0004 \mathrm{~g} / \mathrm{L} \mathrm{D}-$ biotin. They differed with respect to the carbon source concentration: $10 \mathrm{~g} / \mathrm{L}$ glucose for BMD, 1 
and 5\% (by vol.) methanol for BMM2 and BMM10, respectively.

\section{Cloning and engineering of the TVDAO gene, and construction of $P$. pastoris expression cassettes}

Escherichia coli TOP10F' (Invitrogen Corp.) was used as host for all cloning steps. The protein sequence [GenBank: AAR98816] of D-amino acid oxidase from Trigonopsis variabilis ATCC 10679 was employed for the design of a codon optimized gene for over-expression in Pichia pastoris under conditions of methanol induction, using the program Gene Designer (DNA2.0, Menlo Park, CA, USA) with a threshold set at $10 \%$, preferring the best codons. Repetitive codons were manually corrected. The optimized codon usage (see Table 4) was calculated from three highly transcribed genes encoding enzymes of the Pichia pastoris methanol utilization pathway (alcohol oxidase 1 Aox1 [GenBank: U96967]; dihydroxyacetone synthase Das1 [GenBank: FJ754551]; formaldehyde dehydrogenase Fld [Genbank: XP_002493270]) and from a plant gene (Hevea brasiliensis hydroxynitrile lyase $H b$ HNL [Genbank: $\underline{\mathrm{U} 40402}$ ]) that is efficiently expressed in P. pastoris [34]. The resulting gene was made by gene synthesis. The native gene for TvDAO was kindly provided by Ingenza Ltd. (Roslin, UK). Exchange of the putative peroxisomal targeting sequence at the $\mathrm{C}$-terminus of $T v \mathrm{DAO}$ was carried out using a PCR employing a suitable modified reverse primer (see Table 1). Phusion ${ }^{\mathrm{Tu}}$ HighFidelity DNA polymerase was used in this and all other PCR experiments applying a protocol provided by the supplier (Finnzymes Oy, Espoo, Finland).

\section{Construction of $\mathrm{P}$. pastoris expression cassettes}

Products obtained from PCRs were purified with the QIAquick PCR Purification Kit (Qiagen, Hilden, Germany), digested with SpeI and AscI (native TvDAO genes) or EcoRI and NotI (synthetic TvDAO genes). The digested DNA fragments were ligated via SpeI/AscI or EcoRI/NotI restriction sites into equally digested in-house E. coli - P. pastoris shuttle vectors pPpT2 or pPpB1 (TU Graz strain collection BT 5713 and 5709, respectively) that provide single or multi-copy chromosomal integration of target genes in $P$. pastoris, respectively. Relevant features and sequence elements of these shuttle vectors include: origin of replication of the E. coli plasmid pBR322 [35]; the AOX1 promoter $\left(\mathrm{P}_{A O X 1}\right)$ starting with a BglII site; a multiple cloning site with unique restriction sites for EcoRI, SpeI, AscI and NotI; the AOX1 transcription termination sequence; and an antibiotic resistance cassette consisting of a synthetic bacterial promoter called EM72 in tandem with a truncated version of the P. pastoris ILV5 (acetohydroxyacid reductoisomerase) promoter, a synthetic gene coding for the amino acid sequence of bleomycin (ble) conferring resistance against Zeocin from Streptoallotei- chus hindustanus. The ble gene had been codon optimized for function in E. coli as well as P. pastoris. The pPpT2 shuttle vector further contained the $P$. pastoris $A O D$ (alternative oxidase) transcription termination sequence [36] at the 3 ' of the coding sequence of the synthetic ble gene. The pPpB1 vector had the same additional features except that the Saccharomyces cerevisiae ADH1 (alcohol dehydrogenase 1) promoter and terminator controlled the transcription of the ble gene.

\section{Transformation of $\mathrm{P}$. pastoris}

A Mut ${ }^{S}$ strain derived from P. pastoris CBS 7435 (TU Graz strain collection number BT 3132) was used for transformation. A condensed protocol [37] was used in which the shuttle vectors were employed after linearization with BglII and purification with the QIAquick PCR Purification Kit (Qiagen). Transformations were performed in ice-cold electro-transformation cuvettes $(0.2$ $\mathrm{cm}$, Cell Projects Ltd., Kent, UK) using pulse at 200 Ù, 25 $\mu \mathrm{F}$ and $1.5 \mathrm{kV}$. $0.5 \mathrm{~mL}$ of ice-cold sorbitol (1 M; in water) was added immediately after the electro shock, and the suspension was transferred to a sterile $12 \mathrm{~mL}$ polypropylene tube (Greiner, Frickenhausen, Germany). YPD medium $(0.5 \mathrm{~mL})$ was added to the tube which was then incubated for $2 \mathrm{~h}$ at $30^{\circ} \mathrm{C}$ using agitation at $60 \mathrm{rpm}$. After this regeneration step, aliquots $(0.2 \mathrm{~mL})$ were plated on solid selection medium containing $100 \mathrm{mg} / \mathrm{L}$ Zeocin.

\section{Copy number determination by quantitative PCR}

The number of copies of TvDAO expression cassettes integrated into the P. pastoris genome was determined by quantitative real-time PCR as described in [38] employing the endogenous ARG4 gene as a reference. Power SYBR Green PCR Master Mix (Applied Biosystems, Foster City, CA, USA) was used in an ABI PRISM 7300 Real Time PCR System (Applied Biosystems). The following oligonucleotide primers were applied in a concentration of $250 \mathrm{nM}$ when using $2 \mathrm{ng}$ genomic DNA of $P$. pastoris as template: AOX1-fw-RT (gaagctgccetgtcttaaacctt)/AOX1rv-RT (caaaagcttgtcaattggaacca) and ARG4-RT-fw (tcctccggtggcagttctt)/ARG4-RT-rv (tccattgactcccgttttgag). The temperature conditions were: $10 \mathrm{~min}$ at $95^{\circ} \mathrm{C} ; 40$ cycles for $15 \mathrm{~s}$ at $95^{\circ} \mathrm{C}$ and $60 \mathrm{~s}$ at $60^{\circ} \mathrm{C}$ followed by a dissociation step $\left(15 \mathrm{~s}\right.$ at $95^{\circ} \mathrm{C}, 30 \mathrm{~s}$ at $60^{\circ} \mathrm{C}, 15 \mathrm{~s}$ at $\left.95^{\circ} \mathrm{C}\right)$ at the end of the last cycle.

\section{Small-scale cultivation of P. pastoris}

$P$. pastoris transformants were first cultivated in deep well plates (96-well format) using a modified procedure after Weis et al. [28] in a Multitron II stackable incubation system (Infors, Bottmingen, Switzerland). Briefly, following a $60 \mathrm{~h}$ long incubation in $250 \mu \mathrm{L}$ BMD medium $(320 \mathrm{rpm}$, $28^{\circ} \mathrm{C}, 80 \%$ air humidity), the cultures were induced by adding $250 \mu \mathrm{L}$ BMM2. $50 \mu \mathrm{L}$ BMM10 were additionally 
Table 4: Codon usage table designed for high level expression during methanol induction in $P$. pastoris.

\begin{tabular}{|c|c|c|c|c|c|}
\hline Amino acid & Codon & Frequency [\%] & Amino acid & Codon & Frequency [\%] \\
\hline \multirow[t]{4}{*}{ A } & GCU & 54.3 & $\mathrm{P}$ & $\mathrm{CCU}$ & 42.3 \\
\hline & GCC & 23.3 & & $\mathrm{CCC}$ & 6.0 \\
\hline & GCA & 20.5 & & CCA & 52.0 \\
\hline & GCG & 2.0 & & CCG & 0.0 \\
\hline \multirow[t]{2}{*}{ C } & UGU & 70 & $\mathrm{Q}$ & CAA & 66.5 \\
\hline & UGC & 30.0 & & CAG & 33.5 \\
\hline \multirow[t]{2}{*}{ D } & GAU & 33.5 & $\mathrm{R}$ & CGU & 20.2 \\
\hline & GAC & 66.5 & & CGC & 0.0 \\
\hline \multirow[t]{2}{*}{$E$} & GAA & 47.0 & & CGA & 1.2 \\
\hline & GAG & 53.0 & & CGG & 1.2 \\
\hline \multirow[t]{2}{*}{$\mathrm{F}$} & UUU & 31.0 & & AGA & 71.5 \\
\hline & UUC & 69.0 & & AGG & 6.0 \\
\hline \multirow[t]{4}{*}{ G } & GGU & 64.3 & $S$ & UCU & 48.2 \\
\hline & GGC & 8.5 & & UCC & 27.2 \\
\hline & GGA & 25.3 & & UCA & 11.3 \\
\hline & GGG & 2.3 & & UCG & 4.3 \\
\hline \multirow[t]{2}{*}{$\mathrm{H}$} & CAU & 20.0 & & AGU & 4.3 \\
\hline & CAC & 80.0 & & AGC & 4.3 \\
\hline \multirow[t]{3}{*}{ I } & AUU & 52.0 & $\mathrm{~T}$ & $\mathrm{ACU}$ & 46.5 \\
\hline & AUC & 43.7 & & $\mathrm{ACC}$ & 38.0 \\
\hline & $A \cup A$ & 4.3 & & $A C A$ & 9.5 \\
\hline \multirow[t]{2}{*}{ K } & AAA & 25.5 & & ACG & 6.0 \\
\hline & AAG & 74.5 & V & GUU & 48.5 \\
\hline \multirow[t]{6}{*}{ L } & UUA & 11.5 & & GUC & 29.8 \\
\hline & UUG & 43.7 & & GUA & 6.5 \\
\hline & CUU & 21.2 & & GUG & 15.3 \\
\hline & CUC & 7.7 & W & UGG & 100 \\
\hline & CUA & 2.5 & $Y$ & UAU & 22.0 \\
\hline & CUG & 13.5 & & UAC & 78.0 \\
\hline$M$ & AUG & 100 & Stop & UAA & 75.0 \\
\hline \multirow[t]{2}{*}{$\mathrm{N}$} & AAU & 21.5 & & UAG & 0.0 \\
\hline & AAC & 78.5 & & UGA & 25.0 \\
\hline
\end{tabular}

supplied after $\sim 70 \mathrm{~h}$ as well as after $\sim 84 \mathrm{~h}$ total cultivation time. After a $48 \mathrm{~h}$-long induction phase (108 h of cultivation). $50 \mu \mathrm{L}$ of each culture were transferred to V-bottom microtiter plates (Greiner Bio-One \#651101) from which glycerol stocks were prepared. The remainder of the cell suspension was centrifuged (Eppendorf centrifuge 5810R: $3220 \times \mathrm{g}, 4^{\circ} \mathrm{C}, 10 \mathrm{~min}$ ) and the pellets were collected for activity determinations. $300 \mu \mathrm{L}$ Yeast Buster reagent (Novagen, Darmstadt, Germany) were added to the cell pellet which was resuspended and incubated for $\sim 30 \mathrm{~min}$ at room temperature using agitation at $1400 \mathrm{rpm}$ using a TITRAMAX 1000 shaker (Heidolph Instruments GmbH
\& Co. KG, Germany). Following removal of cell debris by centrifugation (Eppendorf centrifuge 5810R: $3220 \times$ g, $\left.4^{\circ} \mathrm{C}, 10 \mathrm{~min}\right), 10 \mu \mathrm{L}$ of the supernatant were employed for measuring $T v \mathrm{DAO}$ activity using the photometric assay as described below.

\section{Bioreactor cultivation of $\mathrm{P}$. pastoris}

The inoculum (optical density $\mathrm{OD}_{600} 10$ - 15) was prepared in two preculture steps in $250 \mathrm{~mL}$ baffled shake flasks using $50 \mathrm{~mL}$ BMGY (10 g/L yeast extract, $20 \mathrm{~g} / \mathrm{L}$ peptone, $100 \mathrm{mM}$ potassium phosphate buffer ( $\mathrm{pH} 6.0)$, $13.4 \mathrm{~g} / \mathrm{L}$ yeast nitrogen base and $10 \mathrm{~g} / \mathrm{L}$ glycerol). Incuba- 
tions were done for about 12 and $8 \mathrm{~h}$ at $28^{\circ} \mathrm{C}$ using agitation at $120 \mathrm{rpm}$ (Certomat BS-1). A 1.5-L fed batch-pro ${ }^{\circ}$ bioreactor system (DASGIP AG, Juelich, Germany) equipped with a six-bladed Rushton turbine impeller and suitable controllers for $\mathrm{pH}$ and dissolved $\mathrm{O}_{2}$ was used for biomass and enzyme production. The basal medium of Invitrogen Corp. was modified according to Hellwig et al. [39] and contained $40 \mathrm{~g} / \mathrm{L}$ glycerol, $0.17 \mathrm{~g} / \mathrm{L}$ calcium sulphate dihydrate, $2.32 \mathrm{~g} / \mathrm{L}$ magnesium sulphate heptahydrate, $2.86 \mathrm{~g} / \mathrm{L}$ potassium sulphate, $7.18 \mathrm{~g} / \mathrm{L}$ aqueous phosphoric acid (85\%), $0.64 \mathrm{~g} / \mathrm{L}$ potassium hydroxide, $0.22 \mathrm{~g} / \mathrm{L}$ sodium chloride, $0.6 \mathrm{~g} / \mathrm{L}$ EDTA disodium dihydrate, $0.20 \mathrm{~mL} / \mathrm{L}$ antifoam (ACEPOL $83 \mathrm{E}$; Lubrizol Additives, Wickliffe, Ohio, USA). PTM 1 trace element solution was added $(4.35 \mathrm{~mL} / \mathrm{L}$ medium) after in situ sterilisation of the basal medium. Its composition was as suggested by Invitrogen, namely $0.2 \mathrm{~g} / \mathrm{L}$ biotin, $6 \mathrm{~g} / \mathrm{L} \mathrm{CuSO}_{4} \times 5 \mathrm{H}_{2} \mathrm{O}$, $80 \mathrm{mg} / \mathrm{L} \mathrm{NaI}, 3.067 \mathrm{~g} / \mathrm{L} \mathrm{MnSO}_{4} \times \mathrm{H}_{2} \mathrm{O}, 0.2 \mathrm{~g} / \mathrm{L} \mathrm{Na}_{2} \mathrm{MoO}_{4}$ $\times 2 \mathrm{H}_{2} \mathrm{O}, 20 \mathrm{mg} / \mathrm{L} \mathrm{H}_{3} \mathrm{BO}_{3}, 0.916 \mathrm{~g} / \mathrm{L} \mathrm{CoCl}_{2} \times 6 \mathrm{H}_{2} \mathrm{O}, 20 \mathrm{~g} /$ $\mathrm{L} \mathrm{ZnCl}_{2}, 65 \mathrm{~g} / \mathrm{L} \mathrm{FeSO}_{4} \times 7 \mathrm{H}_{2} \mathrm{O}$, and $5 \mathrm{~mL} / \mathrm{L} \mathrm{H}_{2} \mathrm{SO}_{4}$. The $\mathrm{pH}$ of the final medium was adjusted to 6.0 using an ammonia solution ( $25 \%$ by volume; technical quality).

The cultivation started from an initial liquid volume of $0.65 \mathrm{~L}$ (in total) with $50 \mathrm{~mL}$ of the $2^{\text {nd }}$ preculture in a batch phase $\left(28^{\circ} \mathrm{C}\right.$, aeration at $\left.0.7 \mathrm{~L} / \mathrm{min}\right)$ in which glycerol served as the sole source of carbon. The stirrer speed varied between 500 and $1200 \mathrm{rpm}$ as required to maintain a level of dissolved $\mathrm{O}_{2}$ greater or equal $30 \%$ air saturation. The ammonia solution was used for $\mathrm{pH}$ control and likewise as nitrogen source. Following depletion of glycerol in the batch phase, typically after $\sim 16-18 \mathrm{~h}$, glycerol was fed from a $700 \mathrm{~g} / \mathrm{L}$ substrate solution containing $12 \mathrm{~mL} / \mathrm{L}$ $\mathrm{PTM}_{1}$ solution. The feed flow rate increased exponentially over $6 \mathrm{~h}$ from $4.77 \mathrm{~mL} / \mathrm{h}$ to $11.72 \mathrm{~mL} / \mathrm{h}$, afterwards gradually decreased to zero within $2 \mathrm{~h}$. Decreasing glycerol supply was accompanied by the start of methanol feeding (supplemented with $12 \mathrm{~mL} / \mathrm{L} \mathrm{PTM} \mathrm{PM}_{1}$ solution). The flow rate was increased linearly to $3 \mathrm{~mL} / \mathrm{min}$ within the $2 \mathrm{~h}$ where the glycerol feed was reduced and remained constant at this high level for another $90 \mathrm{~h}$. Feeding of mix-substrates (methanol/glucose and methanol/glycerol) occurred in the same manner. Both mix fed contained $452 \mathrm{~g} / \mathrm{L}$ methanol and $346 \mathrm{~g} / \mathrm{L}$ glucose or $321 \mathrm{~g} / \mathrm{L}$ glycerol, respectively and were supplemented with 12 $\mathrm{mL} / \mathrm{L} \mathrm{PTM}_{1}$ solution.

Biomass was harvested using an Avanti J-20 XP centrifuge (Beckman Coulter, Krefeld, Germany) employing a JA-10 rotor at $2831 \times \mathrm{g}\left(10 \mathrm{~min}, 4^{\circ} \mathrm{C}\right)$. The pellet was washed once with a $100 \mathrm{mM}$ potassium phosphate buffer $(\mathrm{pH} 6.0)$ and stored frozen $\left(-20^{\circ} \mathrm{C}\right)$ until further use.

For cell lysis the thawed cell mass $(\sim 5 \mathrm{~g})$ was suspended in $10 \mathrm{~mL}$ Tris buffer (100 mM, pH 7.5) and passed 2 times through an Aminco French press using an FA-030 cell (SLM Instruments, Rochester, NY, USA) at approx. 150 bar. Insoluble material was separated from the supernatant by centrifugation ( $20 \mathrm{~min}, 14000 \mathrm{rpm}, 4^{\circ} \mathrm{C}$ ) and further washed three times with $10 \mathrm{~mL}$ Tris buffer as above. Both the supernatant and the insoluble fraction were used for the measurement of TvDAO activity.

\section{Assays for oxidase activity and stability}

An enzyme-coupled colorimetric assay for oxidase activity was used as described by Alexeeva et al. [40] with slight modifications. Briefly, $10 \mu \mathrm{L}$ of appropriately diluted Yeast Buster cell lysate were transferred into a microtiter plate well. Assay solution $(190 \mu \mathrm{L})$ was added and colour development (measured at $510 \mathrm{~nm}$ ) monitored for $5 \mathrm{~min}$ at room temperature. The composition of the assay solution was $100 \mathrm{mM}$ potassium phosphate buffer ( $\mathrm{pH}$ 7.8), $0.5 \mathrm{mM}$ 2,4,6-tribromo-3-hydroxybenzoic acid, $0.75 \mathrm{mM}$ 4-aminoantipyrine, $10 \mathrm{mM}$ D-methionine, and $0.025 \mathrm{mg} / \mathrm{ml}$ horseradish peroxidase (type VIa; Sigma-Aldrich catalogue number P6782).

A direct assay of TvDAO activity used measurement of $\mathrm{O}_{2}$ consumption at $30^{\circ} \mathrm{C}$. A previously described glass mini-reactor with a working volume of $30 \mathrm{~mL}$ was employed [10]. The reactor was equipped with a fibreoptic oxygen micro-optode (PreSens GmbH, Regensburg, Germany), a temperature sensor, and a teflon sparging tube ( $1 \mathrm{~mm}$ internal diameter) through which air $\mathrm{O}_{2}$ was supplied. Mixing was achieved with a magnetic stirrer operated at $300 \mathrm{rpm}$.

Initial rates of $\mathrm{O}_{2}$ conversion were recorded using 10 $\mathrm{mM}$ D-methionine as the substrate dissolved in $10 \mathrm{mM}$ Tris buffer ( $\mathrm{pH}$ 7.5). Reactions were started by adding 20 $\mu \mathrm{L}$ of appropriately diluted $P$. pastoris cell extract, obtained through either lysis or French press disruption of biomass, to $30 \mathrm{~mL}$ of reaction mixture. Alternatively, a suitable amount of untreated or permeabilized yeast cells was added. Note the standard protocol for cell lysis which involved mixing of $100 \mathrm{mg}$ wet biomass with $400 \mu \mathrm{L}$ Yeast Buster reagent followed by incubation of the suspension for $10 \mathrm{~min}$ at $4^{\circ} \mathrm{C}$. One unit of oxidase activity refers to 1 $\mu \mathrm{mol} \mathrm{O}{ }_{2}$ consumed/min under the conditions used. Standard deviation was derived from three independent activity determinations and calculated according to following equation, where $x=$ experimental value and $n=$ number of independent experiments:

$$
\sqrt{\frac{n \sum x^{2}-\left(\sum x\right)^{2}}{n(n-1)}}
$$

A previously reported procedure was applied for the determination of "operational" stability of the different 
oxidase preparations [10]. Air was sparged into the minireactor at a flow rate of $30 \mathrm{~L} / \mathrm{h}$. The substrate solution contained $100 \mathrm{mM}$ D-methionine dissolved in $100 \mathrm{mM}$ Tris buffer (pH 7.5). The reaction was started by addition of a suitable amount of oxidase (cell extract, whole-cell preparation) such that the level of dissolved $\mathrm{O}_{2}$ initially dropped to about $50 \mu \mathrm{M}$ ( $\sim 25 \%$ air saturation). The time course for $\left[\mathrm{O}_{2}\right]$ was then recorded until the concentration of oxygen returned $\sim 100 \%$ air saturation. Data were fitted with an exponential decay function to obtain an estimate for the first-order inactivation constant $k_{\text {in }}[10]$.

\section{Permeabilization}

About $10 \mathrm{~g}$ wet $P$. pastoris biomass was suspended in 10 $\mathrm{mL}$ distilled water and freeze-dried over night using a Christ Alpha 1-4 LSC freeze dryer (Martin Christ Gefriertrocknungsanlagen, Osterode, Germany) operated at $0^{\circ} \mathrm{C}$ and 0.570 mbar. Permeabilization by isopropanol was carried out in a total volume of $1 \mathrm{~mL}$, using $4 \mathrm{mg}$ dried cells unless otherwise stated. The alcohol concentration was varied in the range $2-40 \%$ (by volume, in water). Pure water served as reference. Incubation of the cells was done at $4^{\circ} \mathrm{C}$ without agitation; the time was variable between $20 \mathrm{~min}$ and $50 \mathrm{~h}$ as indicated. $100 \mu \mathrm{L}$ cell suspension was used to measure activity and stability.

\section{Competing interests}

The authors SA, JN, GB, BN and AG declare that they have no competing interests. RS is employed by Ingenza Ltd. who is interested in the commercialization of an industrial chemo-enzymatic process for amino acid deracemization.

\section{Authors' contributions}

SA and GB constructed the various TVDAO expression cassettes and carried out Pichia pastoris strain construction. They performed the screening work and did the bioreactor cultivations. The screening assay was provided by Ingenza. SA also supervised the RT-PCR experiments and interpreted data concerning protein expression. JN performed cell permeabilization experiments and determined the activities and stabilities of whole-cell catalysts. AA and RS provided feedback about the reproducibility of the lab results in scale up experiments at Ingenza. IF, RS, BN and AG made substantial contributions to the conception, design and discussion of the overall project strategy and the experiments. SA, $A G$ and $B N$ wrote the paper. All authors have read and approved the final version of the manuscript.

\section{Acknowledgements}

The authors thank Thorsten Bachler for excellent technical support, and Claudia Ruth for providing Pichia expression vectors. The FFG, the Province of Styria, SFG and Ingenza Ltd. are acknowledged for financial support. JN\&BN acknowledge Slovak-Austrian travel project SK-AT-0024-08.

\section{Author Details}

${ }^{1}$ Austrian Centre of Industrial Biotechnology, c/o Applied Biocatalysis Research Centre, c/o Institute of Molecular Biotechnology, Graz University of Technology, Petersgasse 14, 8010 Graz, Austria, Institute of Biotechnology and Biochemical Engineering, Graz University of Technology, Petersgasse 12, 8010 Graz, Austria, 3 Institute of Chemistry, Center of Glycomics, Slovak Academy of Sciences, Dúbravska cesta 9, SK-84538 Bratislava, Slovak Republic and ${ }^{4}$ Ingenza Ltd., Wallace Building, Roslin BioCentre, Roslin, EH25 9PP, UK

Received: 10 December 2009 Accepted: 26 April 2010 Published: 26 April 2010
References

1. Riethorst W, Reichert A: An industrial view on enzymes for the cleavage of cephalosporin C. Chimia 1999, 53:600-607.

2. Tishkov VI, Khoronenkova SV: D-Amino acid oxidase: Structure, catalytic mechanism, and practical application. Biochemistry (Moscow) 2005, 70:40-54.

3. Pollegioni L, Molla G, Sacchi S, Rosini E, Verga R, Pilone MS: Properties and applications of microbial D-amino acid oxidases: current state and perspectives. Applied Microbiology and Biotechnology 2008, 78:1-16.

4. Rosini E, Molla G, Rossetti C, Pilone MS, Pollegioni L, Sacchi S: A biosensor for all D-amino acids using evolved D-amino acid oxidase. Journal of Biotechnology 2008, 135:377-384.

5. Beard TM, Turner NJ: Deracemisation and stereoinversion of a-amino acids using D-amino acid oxidase and hydride reducing agents. Chemical Communications 2002, 7:246-247

6. Khoronenkova SV, Tishkov VI: D-amino acid oxidase: physiological role and applications. Biochemistry (Moscow) 2008, 73:1511-1518.

7. Kubicek-Pranz EM, Rohr M: D-amino acid oxidase from the yeast Trigonopsis variabilis. Journal of Applied Biochemistry 1985, 7:104-113.

8. Pollegioni L, Caldinelli L, Molla G, Sacchi S, Pilone MS: Catalytic properties of D-amino acid oxidase in cephalosporin C bioconversion: $\mathrm{a}$ comparison between proteins from different sources. Biotechnology Progress 2004, 20:467-473.

9. Dib I, Nidetzky B: The stabilizing effects of immobilization in D-amino acid oxidase from Trigonopsis variabilis. BMC Biotechnology 2008, 8:72

10. Nahalka J, Dib I, Nidetzky B: Encapsulation of Trigonopsis variabilis Damino acid oxidase and fast comparison of the operational stabilities of free and immobilized preparations of the enzyme. Biotechnology and Bioengineering 2008, 99:251-260.

11. Nahalka J, Nidetzky B: Fusion to a pull-down domain: a novel approach of producing Trigonopsis variabilis D-amino acid oxidase as insoluble enzyme aggregates. Biotechnology and Bioengineering 2007, 97:454-461.

12. Vikartovska-Welwardova A, Michalkova E, Gemeiner P, Welward L: Stabilization of D-amino-acid oxidase from Trigonopsis variabilis by manganese dioxide. Folia Microbiologica 1999, 44:380-384.

13. Dib I, Stanzer D, Nidetzky B: Trigonopsis variabilis D-amino acid oxidase: control of protein quality and opportunities for biocatalysis through production in Escherichia coli. Applied and Environmental Microbiology 2007, 73:331-333

14. Gonzalez FJ, Montes J, Martin F, Lopez MC, Ferminan E, Catalan J, Galan MA, Dominguez A: Molecular cloning of TV DAO1, a gene encoding a Damino acid oxidase from Trigonopsis variabilis and its expression in Saccharomyces cerevisiae and Kluyveromyces lactis. Yeast 1997, 13:1399-1408.

15. Isoai A, Kimura H, Reichert A, Schorgendorfer K, Nikaido K, Tohda H, GigaHama Y, Mutoh N, Kumagai H: Production of D-amino acid oxidase (DAO) of Trigonopsis variabilis in Schizosaccharomyces pombe and the characterization of biocatalysts prepared with recombinant cells. Biotechnology and Bioengineering 2002, 80:22-32.

16. Zheng HB, Wang XL, Chen J, Zhu K, Zhao YH, Yang YL, Yang S, Jiang W: Expression, purification, and immobilization of His-tagged D-amino acid oxidase of Trigonopsis variabilis in Pichia pastoris. Applied Microbiology and Biotechnology 2006, 70:683-689.

17. Yu J, Li DY, Zhang YJ, Yang S, Li RB, Yuan ZY: High expression of Trigonopsis variabilis D-amino acid oxidase in Pichia pastoris. Journal of Molecular Catalysis B: Enzymatic 2002, 18:291-297.

18. Fernandez-Lafuente R, Rodriguez V, Guisan JM: The coimmobilization of $D$-amino acid oxidase and catalase enables the quantitative transformation of $D$-amino acids (D-phenylalanine) into a-keto acids (phenylpyruvic acid). Enzyme and Microbial Technology 1998, 23:28-33.

19. Cregg JM, Madden KR, Barringer KJ, Thill GP, Stillman CA: Functional characterization of the two alcohol oxidase genes from the yeast Pichia pastoris. Molecular and Cellular Biology 1989, 9:1316-1323.

20. Gleeson MA, Sudbery PE: The methylotrophic yeasts. Yeast 1988, 4:1-15.

21. Klei IJ van der, Yurimoto $H$, Sakai Y, Veenhuis M: The significance of peroxisomes in methanol metabolism in methylotrophic yeast. Biochimica et Biophysica Acta 2006, 1763:1453-1462.

22. Tan Q, Song QX, Zhang YW, Wei DZ: Characterization and application of D-amino acid oxidase and catalase within permeabilized Pichia pastoris cells in bioconversions. Applied Biochemistry and Biotechnology 2007, 136:279-289. 
23. Emanuelsson $\mathrm{O}$, Brunak $\mathrm{S}$, von Heijne $\mathrm{G}$, Nielsen $\mathrm{H}$ : Locating proteins in the cell using TargetP, SignalP and related tools. Nature Protocols 2007, 2:953-971.

24. Nakai $\mathrm{K}$, Horton P: PSORT: a program for detecting sorting signals in proteins and predicting their subcellular localization. Trends in Biochemical Sciences 1999, 24:34-36.

25. Neuberger G, Maurer-Stroh S, Eisenhaber B, Hartig A, Eisenhaber F: Prediction of peroxisomal targeting signal 1 containing proteins from amino acid sequence. Journal of Molecular Biology 2003, 328:581-592.

26. Neuberger G, Maurer-Stroh S, Eisenhaber B, Hartig A, Eisenhaber F: Motif refinement of the peroxisomal targeting signal 1 and evaluation of taxon-specific differences. Journal of Molecular Biology 2003, 328:567-579

27. Monosov EZ, Wenzel TJ, Luers GH, Heyman JA, Subramani S: Labeling of peroxisomes with green fluorescent protein in living P. pastoris cells. Journal of Histochemistry and Cytochemistry 1996, 44:581-589.

28. Weis R, Luiten R, Skranc W, Schwab H, Wubbolts M, Glieder A: Reliable high-throughput screening with Pichia pastoris by limiting yeast cell death phenomena. FEMS Yeast Research 2004, 5:179-189.

29. Tschopp JF, Brust PF, Cregg JM, Stillman CA, Gingeras TR: Expression of the lacZ gene from two methanol-regulated promoters in Pichia pastoris. Nucleic Acids Research 1987, 15:3859-3876.

30. Zhang W, Hywood Potter KJ, Plantz BA, Schlegel VL, Smith LA, Meagher MM: Pichia pastoris fermentation with mixed-feeds of glycerol and methanol: growth kinetics and production improvement. Journal of Industrial Microbiology and Biotechnology 2003, 30:210-215.

31. d'Anjou MC, Daugulis AJ: A rational approach to improving productivity in recombinant Pichia pastoris fermentation. Biotechnology and Bioengineering 2001, 72:1-11.

32. Lin-Cereghino GP, Lin-Cereghino J, Ilgen C, Cregg JM: Production of recombinant proteins in fermenter cultures of the yeast Pichia pastoris. Current Opinion in Biotechnology 2002, 13:329-332.

33. Pscheidt B, Glieder A: Yeast cell factories for fine chemical and API production. Microbial Cell Factories 2008, 7:25.

34. Hasslacher M, Schall M, Hayn M, Bona R, Rumbold K, Luckl J, Griengl H, Kohlwein SD, Schwab H: High-level intracellular expression of hydroxynitrile lyase from the tropical rubber tree Hevea brasiliensis in microbial hosts. Protein Expression and Purification 1997, 11:61-71.

35. Sutcliffe JG: Complete nucleotide sequence of the Escherichia coli plasmid pBR322. Cold Spring Harbour Symposia on Quantitative Biology 1979, 43:77-90.

36. Kern A, Hartner FS, Freigassner M, Spielhofer J, Rumpf C, Leitner L, Frohlich $\mathrm{KU}, \mathrm{Glieder}$ A: Pichia pastoris 'just in time' alternative respiration. Microbiology 2007, 153:1250-1260.

37. Lin-Cereghino J, Wong WW, Xiong S, Giang W, Luong LT, Vu J, Johnson SD, Lin-Cereghino GP: Condensed protocol for competent cell preparation and transformation of the methylotrophic yeast Pichia pastoris. Biotechniques 2005, 38: 44, 46, 48

38. Abad S, Kitz K, Hormann A, Schreiner U, Hartner FS, Glieder A: Real-time PCR-based determination of gene copy numbers in Pichia pastoris. Biotechnology Journal 2010, 5:413-420.

39. Hellwig S, Emde F, Raven NP, Henke M, Logt P van Der, Fischer R: Analysis of single-chain antibody production in Pichia pastoris using on-line methanol control in fed-batch and mixed-feed fermentations. Biotechnology and Bioengineering 2001, 74:344-352.

40. Alexeeva M, Enright A, Dawson MJ, Mahmoudian M, Turner NJ: Deracemization of a-methylbenzylamine using an enzyme obtained by in vitro evolution. Angewandte Chemie International Edition 2002, 41:3177-3180

doi: $10.1186 / 1475-2859-9-24$

Cite this article as: Abad et al., Stepwise engineering of a Pichia pastoris Damino acid oxidase whole cell catalyst Microbial Cell Factories 2010, 9:24
Submit your next manuscript to BioMed Centra and take full advantage of:

- Convenient online submission

- Thorough peer review

- No space constraints or color figure charges

- Immediate publication on acceptance

- Inclusion in PubMed, CAS, Scopus and Google Scholar

- Research which is freely available for redistribution

Submit your manuscript at www.biomedcentral.com/submit
C Biomed Central 